\title{
POLSKIE PRZEDSIĘBIORSTWA NA RYNKU MIĘDZYNARODOWYM. WYBRANE PROBLEMY
}

\author{
Sylwia Gostkowska-Dźwig, Magdalena Mrozik \\ Politechnika Częstochowska \\ Wydział Zarządzania
}

\begin{abstract}
Streszczenie: Celem niniejszego artykułu jest przedstawienie motywów, sposobów oraz form internacjonalizacji przedsiębiorstw. Ponadto autorki skupiają się na omówieniu wybranych uwarunkowań internacjonalizacji polskich MŚP wraz z przybliżeniem barier oraz korzyści wynikających z tego procesu. Przedstawiono główne powody i formy podejmowania działalności gospodarczej na rynku międzynarodowym.
\end{abstract}

Słowa kluczowe: globalizacja, internacjonalizacja, umiędzynarodowienie, zarządzanie

DOI: $10.17512 /$ znpcz.2016.2.05

\section{Wprowadzenie}

Proces umiędzynarodowienia określany jest często jako działania w kierunku internacjonalizacji, jak również globalizacji. Oba te terminy mogą być odnoszone w stosunku do gospodarki narodowej, sektora przedsiębiorstw, produktów oraz rynków, zarówno zbytu, jak i zaopatrzeniowych. Zjawiska te cechuje przede wszystkim: rosnący i wzajemny wpływ poszczególnych państw, przenikanie coraz większej liczby produktów (sfery materialnej i niematerialnej) między społeczeństwem. Takie przemieszczanie się rezultatów produkcji, wzorców cywilizacyjnych i kulturowych w skali światowej powoduje potrzebę dostosowania się przedsiębiorstw do powszechnie widocznych zmian (Zakrzewska-Bielawska 2009, s. 340), które są wynikiem wielowymiarowych zjawisk kształtowanych przez szereg procesów, gdzie za podstawowe można uznać globalną konkurencję i intensywną współpracę pomiędzy przedsiębiorstwami w skali światowej.

\section{Motywy, sposoby i formy internacjonalizacji przedsiębiorstw}

Internacjonalizacja przedsiębiorstwa jest zjawiskiem wielowątkowym i złożonym, dlatego istnieje wiele definicji tego pojęcia. Większość autorów używa go w odniesieniu do trzech obszarów, takich jak:

- Ogólnoświatowy zasięg, który oznacza przedsiębiorstwo obejmujące swoją działalnością cały świat, w odróżnieniu od przedsiębiorstw o zasięgu np. lokalnym (krajowym) lub regionalnym (kilka krajów).

- Ogólnoświatowa jednorodność, która oznacza przedsiębiorstwo sprzedające ten sam produkt na wszystkich obsługiwanych rynkach geograficznych, w odróżnieniu od produktu dopasowanego do lokalnej specyfiki. 
- Ogólnoświatowa integracja, która oznacza przedsiębiorstwo odczuwające wyraźnie skutki zdarzeń zachodzących w innych krajach, w odróżnieniu od rynku lokalnego, gdzie sytuacja zagraniczna ma znikomy wpływ na poziom cen, dynamikę konkurencji, popyt i obowiązujące mody (de Wit, Meyer 2007, s. 311).

Ekspansja jest jednym z ważnych warunków przyspieszenia rozwoju gospodarczego przedsiębiorstw poprzez lokowanie swojego kapitału za granicą. Zawsze $\mathrm{w}$ trakcie procesu internacjonalizacji przedsiębiorstwa kierują się bardzo różnymi motywami, do których należą między innymi poprawa konkurencyjności, zwiększenie wartości przedsiębiorstwa czy dostęp do tańszych zasobów (Sobiecki, Pietrewicz (red.) 2014, s. 11; Królik 2015, s. 56).

Wiadomą kwestią pozostaje fakt, że głównym celem działalności przedsiębiorstw jest chęć ciągłego zwiększania zysku. Natomiast wyjście ze swoją działalnością poza granice macierzystego kraju jest jednym ze sposobów jego realizacji. Poprzez ekspansję zagraniczną przedsiębiorstwa mogą zwiększać swoje zyski w sposób nieosiągalny lub bardzo trudny do realizacji na rynku krajowym. Sama decyzja o podjęciu ekspansji zagranicznej to bardzo złożony proces. Motywy zagranicznej orientacji przedsiębiorstw (Tabela 1) można podzielić na trzy grupy, tj.: ekonomiczne, rynkowe i prawne (Wacha 2005, s. 47).

Tabela 1. Motywy zagranicznej orientacji przedsiębiorstw

\begin{tabular}{|c|c|c|}
\hline \multicolumn{3}{|c|}{ Motywy zagranicznej orientacji przedsiębiorstw } \\
\hline $\begin{array}{c}\text { Przykładowe czynniki ekono- } \\
\text { miczne }\end{array}$ & Przykładowe czynniki rynkowe & $\begin{array}{c}\text { Przykładowe czynniki } \\
\text { prawne } \\
\end{array}$ \\
\hline $\begin{array}{c}\text { Maksymalizacja efektu. } \\
\text { Ważne miejsce } \\
\text { wskaźnika zyskowności przed- } \\
\text { siębiorstwa i rentowność pro- } \\
\text { dukcji. } \\
\text { Rynek krajowy ma ograniczony } \\
\text { popyt przy pewnym poziomie } \\
\text { sprzedaży. } \\
\text { Dalej idące działania marketin- } \\
\text { gowe przestają być opłacalne. } \\
\text { Zwiększenie rynku } \\
\text { zbytu jest możliwe tylko przez } \\
\text { sprzedaż na rynkach zagranicz- } \\
\text { nych. } \\
\text { Ograniczona ilość czynników } \\
\text { produkcji powoduje wzrost } \\
\text { kosztów wytworzenia . } \\
\text { Możliwość zatrudnienia } \\
\text { tańszych zagranicznych pra- } \\
\text { cowników czy też łatwiejszy } \\
\text { dostęp do surowców. }\end{array}$ & $\begin{array}{c}\text { Jedną z najważniejszych pozy- } \\
\text { cji w tej grupie stanowią in- } \\
\text { strumenty mieszanki marketin- } \\
\text { gowej, które wykorzystuje się w } \\
\text { celu otwarcia na nowe rynki } \\
\text { oraz utrzymania na dotychcza- } \\
\text { sowych. } \\
\text { Możliwość powstania ugrupo- } \\
\text { wania międzynarodowego, } \\
\text { które może doprowadzić do } \\
\text { zwiększenia konkurencyjności. } \\
\text { Image firmy może być budo- } \\
\text { wany wokół nowoczesnego } \\
\text { zinternacjonalizowanego przed- } \\
\text { siębiorstwa. } \\
\text { Dzięki luce technologicznej } \\
\text { występującej między różnymi } \\
\text { krajami, możliwość przedłuże- } \\
\text { nia cyklu życia produktu. }\end{array}$ & $\begin{array}{c}\text { Dopłaty państwa } \\
\text { macierzystego do produk- } \\
\text { cji przeznaczonej na } \\
\text { eksport. } \\
\text { Łagodniejsze przepisy } \\
\text { prawne. } \\
\text { Niższe podatki. } \\
\text { Omijanie barier celnych } \\
\text { i handlowych. }\end{array}$ \\
\hline
\end{tabular}

Źródło: Opracowanie własne na podstawie: (Wacha 2005, s. 48)

Jednak należy pamiętać również o innych aspektach kierujących przedsiębiorcami decydującymi się na takie właśnie rozwiązanie, jakim jest internacjonalizacja. Pierwszym aspektem jest przede wszystkim rozwój samego przedsiębiorstwa po- 
przez: zwiększenie oferty handlowej, rozbudowę systemu sprzedaży oraz zwiększenie elastyczności firmy. Istotną kwestią pozostaje również chęć zwiększenia obrotów. Bowiem zdobycie nowych rynków wiąże się z pozyskaniem nowych klientów. Każde wejście do kolejnego kraju oznacza wzrost liczby odbiorców. To zaś w konsekwencji stanowi zasadniczy argument dla zwiększenia obrotów, co ostatecznie przekłada się na większe przychody (www.internacjonalizacja.com.pl).

Ponadto kolejnymi argumentami przesądzającymi na korzyść internacjonalizacji są: znaczny wzrost konkurencyjności firmy, pozyskanie dodatkowych środków finansowych, chęć przejęcia rynków zagranicznych, zagrożenie konkurencji czy zapełnienie niszy i tworzenie nowych produktów. Niemniej jednak należy zaznaczyć, że każde przedsiębiorstwo będzie miało odmienne motywy podejmowania takiej działalności do ogólnie pojmowanego rozwoju firmy. Sam proces internacjonalizacji może przyjmować różne formy (Tabela 2). Wybór konkretnego rozwiązania zależy od tego, które jest najbardziej korzystne dla danego przedsiębiorstwa.

Tabela 2. Najbardziej popularne formy internacjonalizacji przedsiębiorstw na rynku

\section{Eksport bezpośredni}

Przedsiębiorstwo nie tylko funkcjonuje poza granicami swojego kraju, ale również nawiązuje bezpośrednią współpracę z tamtejszymi klientami. Przedsiębiorca ma większy wpływ na to, jak będzie kształtować się pozycja, marketingowa strategia oraz kierunki rozwoju jego firmy w innych

krajach. W tym przypadku występują stosunkowo wysokie koszty - szczególnie w przypadku budowania wizerunku firmy poza granicami kraju. Eksport bezpośredni można stosować na kilka różnych sposobów. Na przykład przez własną sieć dystrybucji, własne biuro przedstawicielskie bądź dystrybutora lub agenta zagranicznego.

Eksport pośredni

Występuje tu dłuższy łańcuch sprzedażowy. Wywozem, reklamą i sprzedażą towaru w innych krajach zajmuje się firma, która wcześniej od danego przedsiębiorstwa ten towar nabyła. $Z$ finansowego punktu widzenia jest to bardzo korzystna opcja, albowiem nie angażuje po stronie przedsiębiorstwa praktycznie żadnych środków finansowych na marketing i reklamę. Firma ma niewielki wpływ nie tylko na sprzedaż zagraniczną, ale także na wizerunek jej towarów i usług na innych rynkach.

Eksport korporacyjny i inwestycje

Działania te pozwalają na internacjonalizację przedsiębiorstwa przy jednoczesnej minimalizacji kosztów.

Licencjonowanie i franczyza

W przypadku pozyskania franczyzobiorcy koszty ponoszone przez firmę są minimalne i ograniczają się zaledwie do pojedynczych wydatków administracyjnych. Z kolei udzielając licencji, można liczyć na to, że będą wpływać opłaty, które z pewnością zasilą budżet przedsiębiorstwa.

Spółki zależne

Są to spółki: joint venture, spółki stowarzyszone bądź po prostu spółki córki. Podobnie jak w wyżej wymienionych przypadkach forma, którą zdecyduje się przedsiębiorstwo wybrać, zależy przede wszystkim od tego, jak wielkie środki finansowe chcą zainwestować w ten proces oraz jak dalece chce kontrolować spółkę zależną. Oczywiście im więcej kontroli będzie nad spółką, tym więcej pieniędzy należy w nią zainwestować.

Źródło: Informacje dostępne na stronie internetowej http://www.internacjonalizacja.com.pl/ internacjonalizacja/formy-internacjonalizacji-przedsiebiorstw.php 
Reasumując, należy stwierdzić, że proces internacjonalizacji może przyjmować wiele różnorodnych form. Oznacza to, że każde przedsiębiorstwo, które świadomie dąży do rozwoju na rynkach zagranicznych, ma możliwość wyboru najlepszego i najkorzystniejszego sposobu. Istotną kwestią pozostaje fakt, że przedsiębiorstwo nie musi ograniczać się do jednej z nich. Dodatkowo wydajność tego procesu może zwiększyć dowolne połączenie różnych form. Takie działania zależą jednak od wcześniejszej analizy zapotrzebowania i możliwości oraz pożądanego efektu.

\section{Uwarunkowania internacjonalizacji polskich MŚP}

W całym procesie internacjonalizacji MŚP można napotkać wiele barier zarówno wewnętrznych, jak i zewnętrznych, które stanowią o tym, jak duże jest zagrożenie niepowodzenia całego procesu. Wśród podstawowych barier wewnętrznych należy wymienić:

- Niewystarczające środki finansowe. Internacjonalizacja jest niemożliwa bez odpowiednich funduszy, których może zabraknąć z różnych powodów. Jednym z nich jest niewłaściwe szacowanie kosztów całego przedsięwzięcia. Niedoszacowanie wydatków może spowodować, że będą one wyższe niż przeznaczone na ich pokrycie środki, co znacznie utrudni przeprowadzenie całego procesu. Niedobory finansowe mogą też powstać na skutek innych czynników, jak np. inflacji czy ryzyka kursowego, a brak możliwości uzupełnienia tych niedoborów może mieć kluczowe znaczenie dla zaniechania procesu internacjonalizacji.

- Kwestie kadrowe. Brak osób przygotowanych do przeprowadzenia internacjonalizacji stanowi zagrożenie dla całości procesu. Firma może rozwijać się tak długo, jak długo dysponuje pracownikami, którzy będą w stanie ją prowadzić w wyznaczonym kierunku. Obejście tej bariery jest możliwe jedynie dzięki solidnemu przygotowaniu do całego procesu i posiadaniu rezerw kadrowych.

- Integralność procesu. Może okazać się, że z jakiegoś powodu nie są realizowane jego założenia. Stan taki może doprowadzić do zaprzestania tworzenia internacjonalizacji zgodnie z wcześniej przyjętą strategią, a zacznie się działanie nieskoordynowane i niezaplanowane.

Natomiast wśród barier zewnętrznych należy wyszczególnić:

- Bariery polityczne, które mają miejsce w przypadku niestabilności rządów w danym kraju docelowym. Brak stabilności politycznej ma negatywny wpływ na całą ekonomię państwa i regionu.

- Bariery finansowe dotyczące różnic kursowych.

- Bariery komercyjne, czyli np. brak akceptacji towaru czy usługi w momencie wejścia na nowy rynek oraz brak możliwości magazynowania większej ilości produktów, czy też niezdolność do zapłaty za zamówiony przez pośredników towar.

- Bariery prawne dotyczą zwłaszcza państw zbiurokratyzowanych, które celowo wprowadzają ograniczenia dotyczące importu i eksportu. Problem ten jest dość mocno odczuwalny w krajach, które są na etapie tworzenia prawa. 
Można powiedzieć, iż każda aktywność przedsiębiorstwa jest narażona na różnego rodzaju bariery i zagrożenia. W przypadku procesu internacjonalizacji zagrożenia te mogą być wyjątkowo niebezpieczne, ponieważ na szali stawia się środki finansowe, które często pochodzą z zewnętrznych źródeł, czyli kredytów lub dotacji. Dlatego konieczne jest dobre przygotowanie organizacji do rozpoczęcia tego procesu, a także zabezpieczenie się przed jej barierami, jak również wypracowanie rozwiązań łagodzących ich ewentualne skutki.

$\mathrm{Z}$ podejmowanego przez przedsiębiorstwa procesu internacjonalizacji, którego głównym celem i założeniem jest wielokierunkowy rozwój, wynika również wiele korzyści, wśród których warto wymienić następujące (www.internacjonalizacja. com.pl):

- Wzrost sprzedaży, co wiąże się ze zdobywaniem nowych rynków. O ile rynek krajowy jest w pewien sposób ograniczony, a jego chłonność z czasem zostaje wyczerpana, o tyle wejście na rynki zagraniczne daje szereg możliwości pozwalających na dalszą ekspansję, a co za tym idzie - pozyskanie nowych odbiorców towarów i usług. Takie działania bezpośrednio przyczyniają się do zwiększenia produkcji, co ostatecznie przekłada się na większe przychody.

- Wzrost konkurencyjności firmy. Posiadając odbiorców poza granicami, przedsiębiorstwo nabywa istotną wiedzę oraz know-how dotyczące działalności na rynkach odmiennych od krajowego. W perspektywie czasu pozwala to skuteczniej i bardziej efektywnie wchodzić na kolejne rynki zagraniczne. Znacznie zwiększa się też konkurencyjność firmy na rynku lokalnym. Posiadanie klientów za granicą stanowi ważny argument wizerunkowy, będący dowodem na to, iż przedsiębiorstwo jest dynamiczne, elastyczne i spełnia oczekiwania nawet najbardziej wymagających odbiorców.

- Dywersyfikacja przychodów. O ile organizacja o zasięgu lokalnym jest całkowicie uzależniona od sprzedaży na terenie jednego państwa, tak firma, która przeszła internacjonalizację, może swobodniej manipulować strategią działania.

Należy jednak pamiętać, że wyżej wymienione korzyści nie są jedyne. Również rozbudowa kadry, wykorzystywanie nowych i alternatywnych źródeł finansowania, otwartość na nowe inicjatywy, uatrakcyjnianie oferty handlowej przynoszą różnorakie korzyści w wielu aspektach działalności firmy. W praktyce należy więc przyjąć, że internacjonalizacja jest czymś, nad czym powinno zastanowić się każde przedsiębiorstwo, które dąży do dalszego rozwoju.

Podejmując decyzję o wejściu na rynki międzynarodowe, należy identyfikować czynniki warunkujące rozpoczęcie i prowadzenie działalności międzynarodowej nie tylko w sferze ekonomicznej, ale także w społecznej i kulturowej. Na poziomie przedsiębiorstwa jest to związane ze strategią zarządzania, zorientowaniem na rynki międzynarodowe i globalną konkurencją.

Na podstawie badań przeprowadzonych przez Polską Agencję Rozwoju Przedsiębiorczości (Raport o stanie sektora matych i średnich przedsiębiorstw w Polsce w latach 2013-2014) można zidentyfikować czynniki, dzięki którym przedsiębiorstwa rozpoczynają i prowadzą działalność międzynarodową. W Tabeli 3 przedstawiono główne powody podjęcia działalności gospodarczej na rynku międzynarodowym. 
Tabela 3. Glówne powody podejmowania działalności eksportowej

\begin{tabular}{|c|c|}
\hline \multicolumn{2}{|l|}{ Powody podjęcia działalności eksportowej } \\
\hline Perspektywa długofalowej współpracy z partnerem zagranicznym & $47 \%$ \\
\hline Wysoki popyt na rynku zagranicznym & $41 \%$ \\
\hline Możliwość sprzedaży za granicą po wyższej cenie niż w kraju & $40 \%$ \\
\hline Chęć uniknięcia uzależnienia od sprzedaży na rynku krajowym & $26 \%$ \\
\hline Duża konkurencja na rynku krajowym & $25 \%$ \\
\hline Niedostatecznie rozwinięty rynek zbytu na rynku krajowym & $22 \%$ \\
\hline Poprawa wizerunku firmy & $18 \%$ \\
\hline Powiązania właścicielskie z kontrahentem zagranicznym & $14 \%$ \\
\hline Mniejsze ograniczenia administracyjne i regulacyjne za granicą & $12 \%$ \\
\hline
\end{tabular}

Źródło: Opracowanie własne na podstawie: (Raportu z badania... 2014, s. 84)

Z powyższej tabeli wynika, iż u podstaw rozpoczęcia działalności poza granicami kraju przedsiębiorcy najczęściej wskazywali perspektywę długofalowej współpracy z partnerem zagranicznym, wysoki popyt na rynku zagranicznym oraz możliwość sprzedaży za granicą po wyższej cenie niż w kraju. Jednocześnie widać, że umiędzynarodowienie motywowane osiągnięciem większego zysku przekłada się na lepsze wyniki finansowe, a znalezienie partnera biznesowego za granica może być początkiem długofalowej współpracy.

Decyzja o internacjonalizacji przedsiębiorstwa jest przede wszystkim związana z dążeniem do wzrostu zyskowności i dywersyfikacji rynków, a więc ze świadomą realizacją strategii będącą istotnym motywem internacjonalizacji.

Obecnie obserwuje się, że działalność międzynarodową prowadzi co piąte polskie przedsiębiorstwo (21,4\%, ok. 165 tys. podmiotów), nie uwzględniając samozatrudnionych. Skłonność do internacjonalizacji rośnie wraz z wielkością przedsiębiorstwa i jego potencjałem. Najniższa jest dla mikroprzedsiębiorstw, wśród których jedna piąta organizacji podejmuje działania poza rynkiem krajowym. Wśród małych firm grupa podmiotów umiędzynarodowionych stanowi niemal jedną trzecią, a wśród firm średniej wielkości - 46\%. Duże podmioty aktywne na tym polu to $58 \%$. Tak wysoki odsetek umiędzynarodowionych dużych i średnich firm stanowi zdecydowaną mniejszość w strukturze ogółu jednostek prowadzących działalność międzynarodową. Tu dominują mikro oraz małe przedsiębiorstwa, które razem stanowią prawie $95 \%$ populacji umiędzynarodowionych przedsiębiorstw (Raport o stanie... 2015, s. 88).

Dla lepszego zrozumienia działan prowadzonych przez podmioty gospodarcze ich międzynarodową działalność podzielono na czynną i bierną. Pierwsza z nich obejmuje działania związane $\mathrm{z}$ oferowaniem wyrobów i usług na rynku zagranicznym lub obecnością przedsiębiorstwa za granicą, np. eksport, dokonywanie inwestycji bezpośrednich za granicą czy udzielanie licencji podmiotowi zagranicznemu. Natomiast działalność bierna nie wiąże się z obecnością przedsiębiorstw krajowych za granicą, ale dotyczy obecności w danym kraju podmiotów zagranicznych, np. import, napływ zagranicznych inwestycji bezpośrednich do kraju czy zakup licencji od podmiotu zagranicznego. 
Dlatego też należy wziąć pod uwagę fakt, że działalność bierna nie przekłada się na umiędzynarodowienie firm krajowych. Tabela 4 przedstawia działalność czynną oraz import, który jest jedną z form działalności biernej, będący istotnym czynnikiem z perspektywy rozwijającego się kraju, jakim na przykład jest Polska.

Tabela 4. Formy prowadzenia działalności międzynarodowej

\begin{tabular}{|c|c|c|c|c|}
\hline \multirow{2}{*}{ Forma działalności międzynarodowej } & \multirow{2}{*}{$\begin{array}{c}\text { Odsetek pro- } \\
\text { wadzących } \\
\text { działalność }\end{array}$} & \multicolumn{3}{|c|}{$\begin{array}{l}\text { Odsetek prowadzących działalność } \\
\text { międzynarodową }\end{array}$} \\
\hline & & ogółem & czynna & bierna \\
\hline $\begin{array}{l}\text { Prowadzący działalność } \\
\text { międzynarodową }\end{array}$ & $21,39 \%$ & $100 \%$ & - & - \\
\hline Czynna działalność międzynarodowa & $14,78 \%$ & $69,09 \%$ & - & - \\
\hline Bierna działalność międzynarodowa & $14,06 \%$ & $68,51 \%$ & - & - \\
\hline Eksporterzy & $13,66 \%$ & $63,86 \%$ & $92,43 \%$ & - \\
\hline Importerzy & $13,52 \%$ & $63,18 \%$ & - & $92,2 \%$ \\
\hline $\begin{array}{c}\text { Eksportujący i importujący } \\
\text { (jednocześnie) }\end{array}$ & $7,44 \%$ & $34,79 \%$ & - & - \\
\hline Wyłączni eksporterzy & $6,20 \%$ & $28,97 \%$ & $41,94 \%$ & - \\
\hline Wyłączni importerzy & $6,05 \%$ & $28,26 \%$ & - & $41,3 \%$ \\
\hline $\begin{array}{l}\text { Dostawcy w ramach kontraktów na } \\
\text { poddostawy }\end{array}$ & $1,18 \%$ & $5,52 \%$ & $7,99 \%$ & - \\
\hline $\begin{array}{l}\text { Odbiorcy w ramach kontraktu na } \\
\text { poddostawy }\end{array}$ & $2,16 \%$ & $10,08 \%$ & - & $14,7 \%$ \\
\hline Wyłączni dostawcy & $1,12 \%$ & $5,23 \%$ & $7,57 \%$ & - \\
\hline Wyłączni odbiorcy & $2,07 \%$ & $9,69 \%$ & - & $14,1 \%$ \\
\hline $\begin{array}{l}\text { Dostawcy usług w ramach kontraktu na } \\
\text { usługi outsourcingowe }\end{array}$ & $1,18 \%$ & $5,52 \%$ & $7,99 \%$ & - \\
\hline $\begin{array}{l}\text { Odbiorcy usług w ramach kontraktu na } \\
\text { usługi outsourcingowe }\end{array}$ & $0,46 \%$ & $2,13 \%$ & - & $3,1 \%$ \\
\hline Wyłączni dostawcy & $1,04 \%$ & $4,84 \%$ & $7,01 \%$ & - \\
\hline Wyłączni odbiorcy & $0,33 \%$ & $1,55 \%$ & - & $2,3 \%$ \\
\hline $\begin{array}{l}\text { Licencjodawcy w ramach umów } \\
\text { licencyjnych }\end{array}$ & $0,37 \%$ & $1,74 \%$ & $2,52 \%$ & - \\
\hline $\begin{array}{l}\text { Licencjobiorcy w ramach umów } \\
\text { licencyjnych }\end{array}$ & $1,20 \%$ & $5,62 \%$ & - & $8,2 \%$ \\
\hline $\begin{array}{l}\text { Franczyzodawcy w ramach umów } \\
\text { franczyzowych }\end{array}$ & $0,00 \%$ & $0,00 \%$ & $0,00 \%$ & - \\
\hline $\begin{array}{l}\text { Franczyzobiorcy w ramach umów } \\
\text { franczyzowych }\end{array}$ & $0,00 \%$ & $0,00 \%$ & - & $0,0 \%$ \\
\hline $\begin{array}{l}\text { Zarządzający w ramach kontraktów } \\
\text { menedżerskich }\end{array}$ & $0,23 \%$ & $1,07 \%$ & $1,54 \%$ & - \\
\hline $\begin{array}{l}\text { Zlecający zarządzanie w ramach } \\
\text { kontraktów menedżerskich }\end{array}$ & $0,06 \%$ & $0,29 \%$ & - & $0,4 \%$ \\
\hline Posiadający filię zagraniczną & $0,54 \%$ & $2,52 \%$ & $3,65 \%$ & - \\
\hline $\begin{array}{l}\text { Posiadający spółkę joint venture } \\
\text { za granicą }\end{array}$ & $0,08 \%$ & $0,39 \%$ & $0,56 \%$ & - \\
\hline
\end{tabular}

Źródło: (Raport końcowy... 2014, s. 39) 
Analizując powyższe wyniki, należy stwierdzić, iż 21,4\% populacji przedsiębiorstw (bez samozatrudnionych) prowadzi działalność międzynarodową. Niecałe 15\% przedsiębiorstw angażuje się w działalność czynną, tyle samo w bierną. Polskie przedsiębiorstwa najczęściej nawiązują kontrakty handlowe: 13,7\% populacji przedsiębiorstw eksportuje, 13,5\% importuje. Jednocześnie eksportem i importem trudni się siedmiu na stu przedsiębiorców, zaś wyłącznie eksportem lub importem sześć na sto firm. Nieco ponad $2 \%$ przedsiębiorstw to odbiorcy w ramach kontraktów na poddostawy, dostawców w ramach tego typu współpracy jest o połowę mniej - $1 \%$ populacji przedsiębiorstw. Równie niewielu zajmuje się dostawami usług $\mathrm{w}$ ramach kontraktu na usługi outsourcingowe bądź jest licencjobiorcami w ramach umów licencyjnych (po 1\%). Pozostałe formy umiędzynarodowienia przedsiębiorstw są bardzo słabo reprezentowane w populacji firm w Polsce.

\section{Podsumowanie}

Obecnie proces internacjonalizacji jest jednym z największych wyzwań, przed którymi stają przedsiębiorstwa. Pomimo istniejących barier, ograniczeń i uwarunkowań procesy wchodzenia polskich przedsiębiorstw na rynki międzynarodowe jawią się jako coraz bardziej dynamiczne, bazujące na różnorodnych instrumentach wsparcia i innowacyjnych formach działalności (Kempa 2014, s. 33). Przedsiębiorstwa coraz częściej dostrzegają szanse rozwojowe w globalizacji swojej działalności, poprzez skuteczne konkurowanie na rynkach międzynarodowych. Dotyczy to nie tylko dużych firm, ale również małych czy średnich przedsiębiorstw (MŚP), które stają się uczestnikami procesów umiędzynarodowienia. Aczkolwiek należy podkreślić, że bez odpowiednich umiejętności menedżerskich, zasobów ludzkich, potencjału finansowego czy polityki państwa i wyboru odpowiedniej strategii zdecydują o efektywności procesów internacjonalizacji, jak również o możliwościach rozwoju przedsiębiorstwa i dostępie do rynków międzynarodowych.

\section{Literatura}

1. Formy internacjonalizacji przedsiębiorstw, www.internacjonalizacja.com.pl

2. http://www.Artyku\%C5\%82\%202016/ROSS_2013_2014.pdf (dostęp: 18.02.2016).

3. http://www.internacjonalizacja.com.pl/internacjonalizacja/proces-internacjonalizacjiMSP.php (dostęp: 20.03.2016).

4. Kempa E. (2014), Wpływ działań innowacyjnych na rozwój przedsiębiorczości w podmiotach gospodarczych, [w:] Gostkowska-Dźwig S., Mrozik M. (red.), Wyzwania przedsiębiorczości, t. 2, s. 29-36, Sekcja Wydawnictw Wydziału Zarządzania Politechniki Częstochowskiej, Częstochowa.

5. Królik R. (2015), Strategia zrównoważonego rozwoju w obszarze dystrybucji z punktu widzenia producenta paliw, [w:] Brendzel-Skowera K., Łukasik K. (red.), Wyzwania i perspektywy przedsiębiorczej organizacji. Funkcjonowanie i rozwój współczesnych przedsiębiorstw, t. 5, s. 48-58, Sekcja Wydawnictw Wydziału Zarządzania Politechniki Częstochowskiej, Częstochowa.

6. Raport końcowy. Ewaluacja potencjatu eksportowego przedsiębiorstw w Polsce, PARP 2014. 
7. Raport o stanie sektora matych i średnich przedsiębiorstw $w$ Polsce $w$ latach 2013-2014, Agencja Rozwoju Przedsiębiorczości, Warszawa 2015.

8. Sobiecki R., Pietrewicz J.W. (red.) (2014), Ekspansja polskich firm na rynki międzynarodowe, Oficyna Wydawnicza SGH, Warszawa.

9. de Wit B., Meyer R. (2007), Synteza strategii, PWE, Warszawa.

10. Wacha K. (2005), Działalność gospodarcza w Unii Europejskiej. Wybrane zagadnienia, KPilAEwK, Kraków.

11. Zakrzewska-Bielawska A. (2009), Umiędzynarodowienie i globalizacja a strategie rozwoju przedsiębiorstw, [w:] Potocki A. (red.), Instrumenty i obszary przeobrażén i zmian organizacyjnych w warunkach globalizacji, Difin, Warszawa.

\title{
POLISH ENTERPRISE IN THE INTERNATIONAL MARKET. SOME PROBLEMS
}

\begin{abstract}
The aim of this article was to present the motives, methods and forms of internationalization of enterprises. In addition, the author focused on the discussion of selected conditions of internationalization of Polish MSP with an approximation of the barriers and benefits of this process. Outlined the main reasons and mold making business on the international market.
\end{abstract}

Keywords: globalization, internationalization, internationalization, management 